\title{
A phase I trial of ispinesib, a kinesin spindle protein inhibitor, with docetaxel in patients with advanced solid tumours
}

\author{
SP Blagden 1,4,5, LR Molife ${ }^{1,5}$, A Seebaran², M Payne², AHM Reid', AS Protheroe², LS Vasist ${ }^{3}$, DD Williams ${ }^{3}$, \\ C Bowen ${ }^{3}$, SJ Kathman ${ }^{3}$, JP Hodge ${ }^{3}, M_{M}$ Dar $^{3}$, JS de Bono, ${ }^{*, 1}$ and MR Middleton ${ }^{2}$ \\ 'Royal Marsden Hospital and Institute of Cancer Research, Downs Road, Sutton, Surrey SM2 5PT, UK; ${ }^{2}$ Medical Oncology Unit, Cancer Research UK, \\ Oxford Radcliffe Hospitals NHS Trust, The Churchill Hospital, Old Road, Headington, Oxford OX3 7LJ, UK; ${ }^{3}$ GlaxoSmithKline Research and Development \\ and Clinical Pharmacokinetics, Clinical Pharmacology and Discovery Medical Oncology, Research Triangle Park, NC 27709, USA; ${ }^{4}$ Section of Molecular \\ Therapeutics, Division of Surgery, Department of Oncology, Oncology, Reproduction and Anaesthetics, Imperial College London, Hammersmith Hospital, \\ Du Cane Road, London WI 2 OHS, UK
}

The aim of this study is to define the maximum tolerated dose (MTD), safety, pharmacokinetics (PKs) and efficacy of ispinesib (SB-7/5992) in combination with docetaxel. Patients with advanced solid tumours were treated with ispinesib $\left(6-12 \mathrm{mg} \mathrm{m}^{-2}\right)$ and docetaxel $\left(50-75 \mathrm{mg} \mathrm{m}^{-2}\right.$ ). Docetaxel was administered over I h followed by a I-h infusion of ispinesib on day I of a 21 -day schedule. At least three patients were treated at each dose level. Blood samples were collected during cycle I for PK analysis. Clinical response assessments were performed every two cycles using RECIST guidelines. Twenty-four patients were treated at four dose levels. Prolonged neutropaenia and febrile neutropaenia were dose limiting in six and two patients, respectively. The MTD was ispinesib $10 \mathrm{mg} \mathrm{m}^{-2}$ with docetaxel $60 \mathrm{mg} \mathrm{m}^{-2}$. Pharmacokinetic assessment demonstrated concentrations of ispinesib and docetaxel, consistent with published data from single agent studies of the drugs. Seven patients (six hormone refractory prostate cancer (HRPC), one renal cancer) had a best response of stable disease ( $\geqslant 18$ weeks). One patient with HRPC had a confirmed $>50 \%$ prostatic-specific antigen decrease. The MTD for ispinesib and docetaxel was defined and the combination demonstrated an acceptable toxicity profile. Preliminary PK data suggest no interaction between ispinesib and docetaxel.

British Journal of Cancer (2008) 98, 894-899. doi: I0.1038/sj.bjc.6604264 www.bjcancer.com

Published online 4 March 2008

(c) 2008 Cancer Research UK

Keywords: docetaxel; kinesin spindle protein; mitotic kinesin; phase I; SB-7/5992

Mitotic kinesins are a subset of the kinesin enzyme super family, and they are involved in the establishment and function of the mitotic spindle as well as cell cycle progression (Wood et al, 2001). In contrast to tubulin, mitotic kinesins are preferentially expressed in proliferating cells, with specific activity during mitosis, and are thus an attractive molecular target for anticancer therapy (Sakowicz et al, 2004). Kinesin spindle protein (KSP, Eg5, kinesin-5) provides the propulsive forces required to separate centrosomes during prophase, enabling them to migrate to opposite poles and establish a functional bipolar spindle (Blangy et al, 1995). Kinesin spindle protein is greatly expressed in proliferating over non-proliferating cells and in tumour tissue relative to normal tissue (Hegde et al, 2003). In in vitro experiments, cells treated with the prototype KSP inhibitor, monastrol, displayed abnormal, monopolar spindles with chromosomes attached via microtubules to a single pole, resulting in deranged cell division, mitotic cell cycle arrest and apoptosis (Mayer et al, 1999; Cochran et al, 2005).

*Correspondence: Dr JS de Bono; E-mail: johann.de-bono@icr.ac.uk

${ }^{5}$ These two are the joint first authors

Received 3 December 2007; revised 10 January 2008; accepted 17 January 2008; published online 4 March 2008
Ispinesib (SB-715992), a potent and selective small molecule inhibitor of KSP, functions by inhibiting KSP ATPase and is 40000 times more selective for KSP compared to other kinesins (Johnson et al, 2002). In preclinical studies, ispinesib inhibited growth in a wide range of human and murine cell lines with $\mathrm{IC}_{50}$ values of $1.2-9.5 \mathrm{nM}$. Treatment of SKOV3 ovarian tumour cells in vitro with $20 \mathrm{~nm}$ of ispinesib, or a Colo 205 colon cancer murine xenograft model with $30 \mathrm{mg} \mathrm{kg}^{-1}$ of intraperitoneal ispinesib, caused mitotic arrest with cells demonstrating unseparated centrosomes and monopolar mitotic spindles. Tumour growth delay was observed in xenograft models of colon (HT29, Colo201, Colo205), non-small cell lung (Calu-3) and pancreatic (Panc-01) cancers.

Phase I studies have evaluated three schedules of ispinesib administered on days $1-3$ every 21 days, day 1 every 21 days and days 1, 8 and 15 every 28 days (Chu et al, 2003, 2004; Burris et al, 2004). In all studies, the dose-limiting toxicity (DLT) was prolonged neutropaenia or febrile neutropaenia. Other toxicities were mild with no significant neurotoxicity observed. Phase II studies are either ongoing or have been completed in multiple tumour types (Miller et al, 2005; Shahin et al, 2007).

A $9 \%$ objective response rate was observed in patients with metastatic breast cancer who had relapsed or were refractory to prior anthracycline and taxane therapy (Miller et al, 2005). Ispinesib has been evaluated in combination with both carboplatin and capecitabine in two phase I studies of 28 and 24 patients, 
respectively. The maximum tolerated dose (MTD) in both studies has been reported (Jones et al, 2006; Rodon et al, 2006).

This phase I study combines ispinesib with docetaxel. Docetaxel, a member of the taxane family, has activity in breast cancer, nonsmall cell lung cancer (NSCLC) and hormone refractory prostate cancer (HRPC) (Chan et al, 1999; Nabholtz et al, 1999; Fossella et al, 2000, 2003; Shepherd et al, 2000; Tannock et al, 2004). It is currently approved in several indications:

(i) As second-line monotherapy for locally advanced or metastatic breast cancer (Taxotere $\left.{ }^{\circledR}, 2005\right)$.

(ii) In combination with doxorubicin and cyclophosphamide for the adjuvant treatment of node-positive early breast cancer (Taxotere $^{\circledR}, 2005$ ).

(iii) In locally advanced or metastatic NSCLC as first-line therapy in combination with cisplatin or as second-line monotherapy.

(iv) In advanced gastric and gastro-oesophageal junction adenocarcinoma, it is approved as first-line therapy in combination with cisplatin and fluorouracil.

(v) In squamous cell carcinoma of the head and neck as induction treatment for inoperable locally advanced disease with cisplatin and fluorouracil.

(vi) In combination with prednisone for patients with HRPC (Taxotere $\left.^{\mathbb{R}}, 2005\right)$.

Docetaxel binds reversibly to the beta subunit of tubulin, promoting microtubule assembly and stability, thereby blocking the cell cycle in mitosis (Eisenhauer and Vermorken, 1998). Myelosuppression is the DLT of docetaxel and occurs in $>75 \%$ of patients treated with $60 \mathrm{mg} \mathrm{m}^{-2}$ (Taxotere $\left.{ }^{\circledR}, 2005\right)$. Peripheral sensory neuropathy is another prominent toxicity, thought to occur as a result of tubulin stabilisation disrupting the architecture of non-dividing neuronal cells. Both docetaxel and ispinesib can induce mitotic arrest and apoptotic cell death; however, in the MX-1 tumour mouse xenograft model, preclinical data demonstrated synergy when both agents were used concurrently (data on file at GlaxoSmithKline).

The primary objectives of this study were to determine the safety and MTDs of ispinesib and docetaxel in combination. Secondary objectives were to define the pharmacokinetic (PK) profiles of both agents and their efficacy.

\section{MATERIALS AND METHODS}

Eligible patients were recruited from The Royal Marsden Hospital, Sutton, and the Churchill Hospital, Oxford. GlaxoSmithKline sponsored the study. The study obtained full ethical approval and was conducted in accordance with ICH-GCP guidelines.

\section{Patient eligibility}

Patients with histologically confirmed locally advanced or metastatic solid tumours, refractory to conventional therapy or for which no standard therapy exists, were eligible provided they met the following criteria: age $\geqslant 18$; Eastern Co-operative Oncology Group (ECOG) performance status (PS) $0-1$; life expectancy of $\geqslant 12$ weeks; adequate haematopoietic (absolute neutrophil count $\left(\right.$ ANC) $\geqslant 1.5 \times 10^{9} 1^{-1}$, platelet count $\geqslant 100 \times 10^{9} 1^{-1}$, haemoglobin $\geqslant 9 \mathrm{~g} \mathrm{dl}^{-1}$ ), hepatic (transaminases $<2 \times$ upper limit of normal $(\mathrm{ULN})$ or $<1.5 \times$ ULN if alkaline phosphatase $\geqslant 3 \times \mathrm{ULN}$, bilirubin $\leqslant \mathrm{ULN}$ ) and renal function (creatinine clearance $>40 \mathrm{ml} \mathrm{min}^{-1}$ (calculated by the Cockroft-Gault Formula)) (Drinka and Langer, 1989); and a negative pregnancy test for females of child-bearing potential.

Exclusion criteria included the following: pre-existing neuropathy $\geqslant$ grade 2 ; unstable or pre-existing major medical conditions; evidence of symptomatic or uncontrolled brain metastases or leptomeningeal disease; major surgery or any anticancer therapy within the previous 4 weeks; lactating females; and unwillingness to use barrier contraception throughout the trial.

\section{Screening and study procedures}

A full medical history and physical examination including PS, baseline symptoms, adverse events, vital sign assessment, haematology, coagulation and clinical chemistry were performed at baseline and prior to each treatment. A pregnancy test for females was performed prior to study entry only. Twelve-lead electrocardiograms were performed at baseline, prior to cycle 1 and immediately following the end of ispinesib infusion on day 1 , cycle 1. Clinical chemistry, haematology and adverse event assessments were performed at days 8 and 15 of each cycle. Tumour assessment by computed tomography or magnetic resonance imaging, as defined by the RECIST guidelines (Therasse et al, 2000), was performed within 21 days prior to first treatment and every two cycles thereafter until discontinuation from the study. Patients were withdrawn from the study in the event of progressive disease (PD), unacceptable toxicity, withdrawal of consent or at the physician's discretion.

\section{Drug administration}

Ispinesib was supplied by GlaxoSmithKline as a clear colourless solution in 4,5 or $10 \mathrm{ml}$ vials containing a $1 \mathrm{mg} \mathrm{ml}^{-1}$ solution of drug. Docetaxel (Taxotere ${ }^{\circledR}$ Sanofi-Aventis) was diluted as per the prescribing information.

All patients were premedicated with dexamethasone $8 \mathrm{mg}$ p.o. b.i.d. for 3 days starting at day 0 . On day 1, docetaxel was first administered as a $1 \mathrm{~h}$ i.v. infusion, followed by ispinesib, in $250 \mathrm{ml}$ of $5 \%$ glucose administered i.v. over $1 \mathrm{~h}$. The regimen was repeated every 21 days. Post-treatment anti-emetics comprised of domperidone $20 \mathrm{mg}$ p.o. q.d.s.

\section{Dose escalation, definition of DLT and MTD}

The starting dose of ispinesib was $8 \mathrm{mg} \mathrm{m}^{-2}$ (Chu et al, 2004). The starting dose of docetaxel was $60 \mathrm{mg} \mathrm{m}^{-2}$, selected on the basis of the anticipated myelotoxic profile of the combination. The planned dose escalation schedule is shown in Table 1.

Patients were treated in cohorts of three. In the absence of DLT, dose escalation continued in successive cohorts of three patients when three patients at the preceding dose level had completed a 21-day cycle. If one of the three patients experienced a DLT, an additional three patients were recruited to the same dose level. If no further DLTs were observed, dose escalation proceeded. If a second DLT was seen in the cohort of six, the MTD was exceeded and the dose below this was determined as the MTD.

Table I Planned dose escalation schema of ispinesib and docetaxel

\begin{tabular}{lcc}
\hline & \multicolumn{2}{c}{ Dose per $\mathbf{3}$ weekly cycle } \\
\cline { 2 - 3 } Cohort/dose level & Ispinesib & Docetaxel \\
\hline-2 & $6 \mathrm{mg} \mathrm{m}^{-2}$ & $50 \mathrm{mg} \mathrm{m}^{-2}$ \\
-1 & $6 \mathrm{mg} \mathrm{m}^{-2}$ & $60 \mathrm{mg} \mathrm{m}^{-2}$ \\
$\mathbf{0}$ & $\mathbf{8} \mathbf{~ m ~ m ~}^{-2}$ & $\mathbf{6 0} \mathbf{~ m g ~ m}^{-2}$ \\
$A$ & $10 \mathrm{mg} \mathrm{m}^{-2}$ & $60 \mathrm{mg} \mathrm{m}^{-2}$ \\
+1 & $8 \mathrm{mg} \mathrm{m}^{-2}$ & $75 \mathrm{mg} \mathrm{m}^{-2}$ \\
$A$ & $10 \mathrm{mg} \mathrm{m}^{-2}$ & $75 \mathrm{mg} \mathrm{m}^{-2}$ \\
+2 & $12 \mathrm{mg} \mathrm{m}^{-2}$ & $75 \mathrm{mg} \mathrm{m}^{-2}$ \\
+3 & $15 \mathrm{mg} \mathrm{m}^{-2}$ & $75 \mathrm{mg} \mathrm{m}^{-2}$ \\
+4 & $18 \mathrm{mg} \mathrm{m}^{-2}$ & $75 \mathrm{mg} \mathrm{m}^{-2}$ \\
\hline
\end{tabular}

Text in bold indicates the starting dose. Text in italics indicates alternative dose levels that were planned if clarification of the MTD was required. 
Toxicities were graded according to the National Cancer Institute Common Terminology Criteria for Adverse Events Version 3.0 (NCI-CTCAE v 3.0). Dose-limiting toxicity was defined as any of the following: $\geqslant$ grade 3 clinically significant nonhaematological toxicity (excluding $\geqslant$ grade 3 nausea, vomiting or alopaecia), $\geqslant$ grade 3 nausea/vomiting/diarrhoea uncontrolled by aggressive therapy, grade 4 neutropaenia lasting $\geqslant 5$ days, grade 3 or 4 neutropaenia with fever $\geqslant 38.5^{\circ} \mathrm{C}$ or infection, grade 4 thrombocytopaenia, inability to commence next cycle of treatment within 2 weeks of scheduled dosing due to an unresolved toxicity such that the original eligibility criteria were no longer met, grade 2 toxicity, which is considered a DLT by the investigator, $\geqslant$ grade 2 non-haematological toxicity that persisted beyond cycle 1 and was considered a DLT by the investigator.

\section{Dose modification}

Each new cycle of treatment was administered only if the following criteria were met: ANC $>1.5 \times 10^{9} 1^{-1}$, platelet count $>100 \times 10^{9} 1^{-1}$ and recovery from all clinically significant,

Table 2 Patient characteristics

\begin{tabular}{lc}
\hline Number of patients & 24 \\
Median age, years (range) & $61.2(41-76)$ \\
Gender, M/F & $21 / 3$ \\
Race & \\
White & 24 \\
ECOG PS & \\
0 & \\
IUnknown & 9 \\
& 14 \\
Tumour type & 1 \\
Prostate & \\
Duodenal adenocarcinoma & \\
Cervix & \\
Bladder & 14 \\
Renal & 2 \\
Colon & 2 \\
Melanoma & 1 \\
Esophageal & 2 \\
Previous treatment & 1 \\
Chemotherapy & 1 \\
Median number of previous chemotherapy regimens (range) & $1.5(1-3)$ \\
Radiotherapy & 10 \\
Surgery & 9 \\
Biological therapy & 1 \\
\hline
\end{tabular}

$E C O G=$ Eastern Cooperative Group; $F=$ female; $M=$ male; $P S=$ performance status ${ }^{a}$ All chemonaive. ${ }^{b}$ Previous immunotherapy. non-haematological toxicity (apart from alopaecia) to $\leqslant$ grade 1 . Treatment could be delayed for up to 2 weeks to allow these criteria to be met, otherwise treatment was discontinued.

In the case of DLT, on recovery to re-treatment criteria, the doses of both ispinesib and docetaxel were reduced 1 dose level for the subsequent cycle (Table 1 ). In the case of grade 2 neuropathy, treatment was withheld until resolved to grade 1 and the dose of docetaxel alone was reduced by 1 dose level. Colony-stimulating factors were prohibited during cycle 1 of treatment, but could be used in cases of febrile neutropaenia in subsequent cycles.

\section{Pharmacokinetic sampling}

Plasma PK sampling was carried out on day 1 of cycle 1 . A $4 \mathrm{ml}$ blood sample was taken at the following time points relative to the docetaxel infusion: prior to and 1, 2, 4-6 and $24 \mathrm{~h}$ after the end of docetaxel infusion. Further sampling for a pPK interaction was to be performed at the MTD, if this was found to be less than dose level +3 (Table 1 ).

Ispinesib and docetaxel were extracted from plasma samples and then analysed by HPLC-MS/MS using a TurboIonSpray ${ }^{\mathrm{TM}}$ interface and multiple reaction monitoring by the GlaxoSmithKline Division of Drug Metabolism and Pharmacokinetics.

\section{RESULTS}

Twenty-four patients (21 male, 3 female), with a median age of 61.2 years, were treated between June 2004 and June 2005 (Table 2). A wide range of tumour types was treated, with the most common tumour type being HRPC.

\section{Dose-limiting toxicities}

Table 3 summarises the number of patients treated, cycles administered and DLTs per dose level. Patients received a median of three cycles of treatment (range 1-10). Six patients received six or more cycles of treatment and 18 discontinued treatment prematurely due to PD (12), adverse events (4), physician choice (1) and patient choice (1). At dose level 0 (ispinesib $8 \mathrm{mg} \mathrm{m}^{-2}$ and docetaxel $60 \mathrm{mg} \mathrm{m}^{-2}$ ), a patient with HRPC experienced a DLT of prolonged grade 4 neutropaenia during course 1 . The cohort was thus expanded to six patients. There were no further DLTs.

At $8 \mathrm{mg} \mathrm{m}^{-2}$ ispinesib and docetaxel $75 \mathrm{mg} \mathrm{m}^{-2}$, after an initial patient with colorectal adenocarcinoma experienced a DLT of prolonged grade 4 neutropaenia, the cohort was expanded to a total of six patients. The second patient experienced prolonged grade 4 neutropaenia with fever. In order to further clarify the MTD, dose level $\mathrm{A}$, at $10 \mathrm{mg} \mathrm{m}^{-2}$ ispinesib and docetaxel $60 \mathrm{mg} \mathrm{m}^{-2}$, was evaluated. There were no DLTs in the three patients treated at this dose level. In view of recurrent prolonged neutropaenia, we modified the dose escalation procedure to

Table 3 Dose levels, number of cycles administered and dose-limiting toxicities

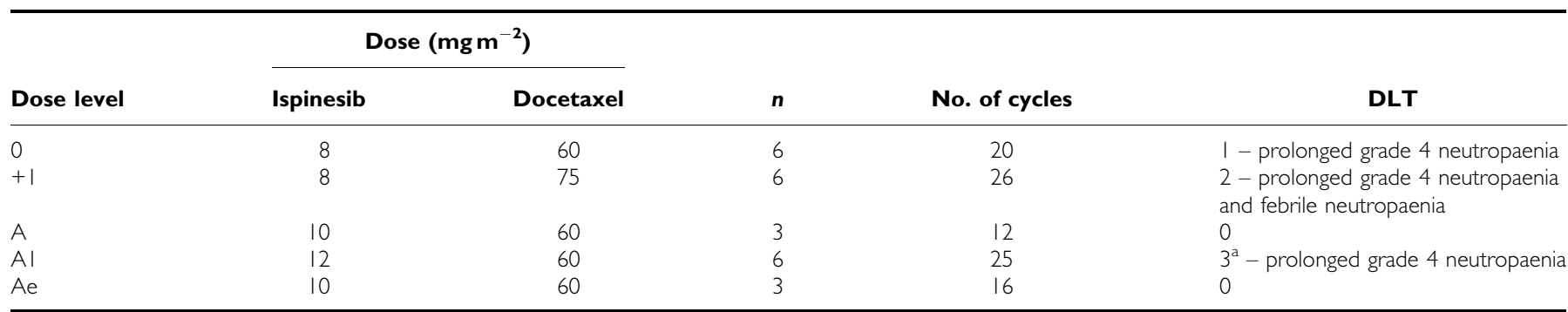

$\mathrm{A}=$ alternative dose level; $\mathrm{Ae}=$ expansion of cohort $\mathrm{A}$ at MTD; $n=$ number of patients; No. = number. ${ }^{\mathrm{a}} \geqslant 2 \mathrm{DLT}$ in cohort due to simultaneous enrolment of patients. 
maintain the dose of docetaxel at $60 \mathrm{mg} \mathrm{m}^{-2}$ and increase the dose of ispinesib only.

In cohort $\mathrm{A} 1$, ispinesib was administered at $12 \mathrm{mg} \mathrm{m}^{-2}$ and docetaxel at $60 \mathrm{mg} \mathrm{m}^{-2}$. After a patient with renal carcinoma developed prolonged grade 4 neutropaenia, the cohort was expanded to six patients. A further two patients - one with duodenal carcinoma and a second with squamous cell carcinoma of the cervix - experienced prolonged grade 4 neutropaenia. With three out of six patients at this dose level experiencing DLT, the MTD was defined as ispinesib $10 \mathrm{mg} \mathrm{m}^{-2}$ and docetaxel $60 \mathrm{mg} \mathrm{m}^{-2}$. The MTD cohort was expanded by a further three patients with no further DLTs.

\section{Haematological toxicity}

All patients were evaluable for toxicity. Table 4 summarises drugrelated haematological toxicities experienced by patients; the most common was neutropaenia in $83 \%(n=20)$ patients. Eighteen of the twenty-four (75\%) patients experienced grade 3 or 4 neutropaenia, and in six of these, prolonged grade 4 neutropaenia constituted a DLT. Four patients developed febrile neutropaenia. Anaemia was significant (grade 3 or 4 ) in three patients. Grade 4

Table 4 Summary of drug-related haematological toxicities (all cycles)

\begin{tabular}{lcccccc}
\hline Toxicity & Grade & $\mathbf{8 / 6 0}^{\mathbf{a}}$ & $\mathbf{8 / 7 5 ^ { \mathbf { a } }}$ & $\mathbf{1 0 / 6 0 ^ { \mathbf { a } }}$ & $\mathbf{1 2 / \mathbf { 6 0 } ^ { \mathbf { a } }}$ & Total (\%) \\
\hline Anaemia & $1-2$ & - & 3 & 2 & 1 & $6(25)$ \\
& $3-4$ & - & - & 1 & 2 & $3(13)$ \\
Neutropaenia & $1-2$ & 1 & - & 1 & - & $2(8)$ \\
& $3-4$ & 4 & 5 & 4 & 5 & $18(75)$ \\
Febrile neutropaenia & $1-2$ & - & - & - & - & $0(0)$ \\
& $3-4$ & - & 2 & - & 2 & $4(17)$ \\
Leukopaenia & $1-2$ & - & & 1 & & $1(4)$ \\
& $3-4$ & 2 & 3 & 1 & 1 & $7(29)$ \\
Thrombocytopaenia & $1-2$ & - & - & 2 & & $2(8)$ \\
& $3-4$ & - & - & - & 1 & $1(4)$ \\
\hline
\end{tabular}

${ }^{a}$ Dose ispinesib/dose docetaxel $\left(\mathrm{mg} \mathrm{m}^{-2}\right)$.

Table 5 Summary of drug-related non-haematological toxicities in $\geqslant 25 \%$ of patients

\begin{tabular}{|c|c|c|c|c|c|c|}
\hline Toxicity & Grade & $8 / 60^{a}$ & $8 / 75^{a}$ & $10 / 60^{a}$ & $12 / 60^{\mathrm{a}}$ & Total (\%) \\
\hline \multirow[t]{2}{*}{ Lethargy/fatigue } & $\mid-2$ & 4 & 5 & 5 & 3 & $17(7 \mid)$ \\
\hline & $3-4$ & 0 & 0 & 1 & 0 & I (4) \\
\hline \multirow[t]{2}{*}{ Nausea } & $1-2$ & 3 & 0 & 5 & 5 & $13(54)$ \\
\hline & $3-4$ & 0 & 0 & 0 & I & I (4) \\
\hline \multirow[t]{2}{*}{ Vomiting } & $1-2$ & 3 & I & 3 & 3 & $10(42)$ \\
\hline & $3-4$ & 0 & 0 & 0 & I & I (4) \\
\hline \multirow[t]{2}{*}{ Diarrhoea } & $1-2$ & I & I & 4 & 2 & $8(33)$ \\
\hline & $3-4$ & I & I & 0 & I & $3(13)$ \\
\hline \multirow[t]{2}{*}{ Alopaecia } & $1-2$ & 2 & 2 & 2 & 2 & $8(33)$ \\
\hline & $3-4$ & 0 & 0 & 0 & 0 & \\
\hline \multirow[t]{2}{*}{ Dysgeusia } & $1-2$ & I & I & 2 & 2 & $6(25)$ \\
\hline & $3-4$ & 0 & 0 & 0 & 0 & \\
\hline
\end{tabular}

${ }^{a}$ Dose ispinesib/dose docetaxel $\left(\mathrm{mg} \mathrm{m}^{-2}\right)$. thrombocytopaenia was seen in one patient that was due to an idiopathic immune thrombocytopaenic purpura, with no clear relationship to study drug; the patient was on concomitant medication (quinine) that could have contributed to this. This thrombocytopaenia resolved with corticosteroid therapy. Overall, there was no evidence of cumulative myelosuppression with repeated dosing.

\section{Non-haematological toxicity}

The most frequent drug-related non-haematological toxicities, occurring in $\geqslant 25 \%$ of patients, are shown in Table 5 . These comprised fatigue in $75 \%$ of patients, nausea in $58 \%$ and diarrhoea and vomiting in $46 \%$ of patients. Thirty-three per cent of patients experienced alopaecia and $25 \%$ dysgeusia. Constipation, cough and headache were seen in $17 \%$ of patients, each generally at grades 1-2 only (with 1 patient at dose level +1 experiencing grade 3 constipation). Peripheral neuropathy was mild and infrequent, being reported at grade 1 in five patients (two at dose level +1 , one at dose level A and two at dose level A1) and grade 2 in two patients only (one each at dose levels 0 and A1). Mucositis was not reported. Overall, all toxicities were manageable, and there were no treatment-related deaths.

\section{Pharmacokinetics}

Plasma concentrations from $\mathrm{PK}$ sampling were compared to plasma concentrations from phase I studies of ispinesib. A population PK analysis was conducted using NONMEM (Globomax LLC, Hanover, MD, USA) on phase I ispinesib data following an $18 \mathrm{mg} \mathrm{m}^{-2}$ dose, the MTD from a once every 21 -day schedule (Chu et al, 2004). Using a validated population model, observed ispinesib concentration - time data from this study were overlaid on the simulated profile. Observed docetaxel data from subjects in this study administered 60 and $75 \mathrm{mg} \mathrm{m}^{-2}$ were overlaid with historical data from subjects dosed with 35,75 and $100 \mathrm{mg} \mathrm{m}^{-2}$ docetaxel (Baker et al, 2003) to ascertain if an interaction was observed affecting docetaxel concentration-time profiles.

Using this model, ispinesib plasma concentrations in cycle 1 were consistent with those observed in phase I studies, as shown in Figure 1. Docetaxel PK parameters were consistent with those reported historically despite the co-administration of ispinesib (Figure 2; Baker et al, 2003).

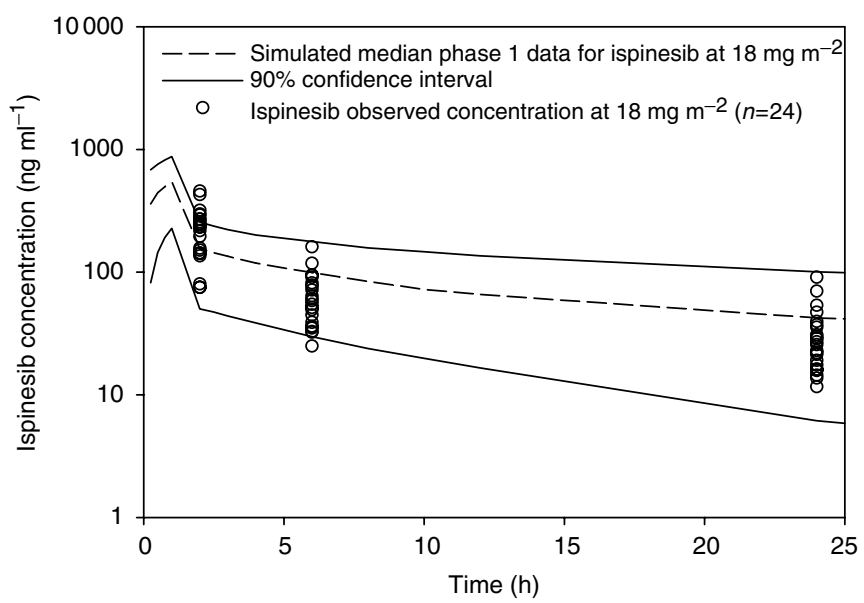

Figure I Simulated vs observed ispinesib concentration-time profiles at $18 \mathrm{mg} \mathrm{m}^{-2}$. Simulation of ispinesib concentrations based on population PK model developed from data collected in a single agent, first in human study of ispinesib in which subjects were dosed from $1-21 \mathrm{mg} \mathrm{m}^{-2}$. 


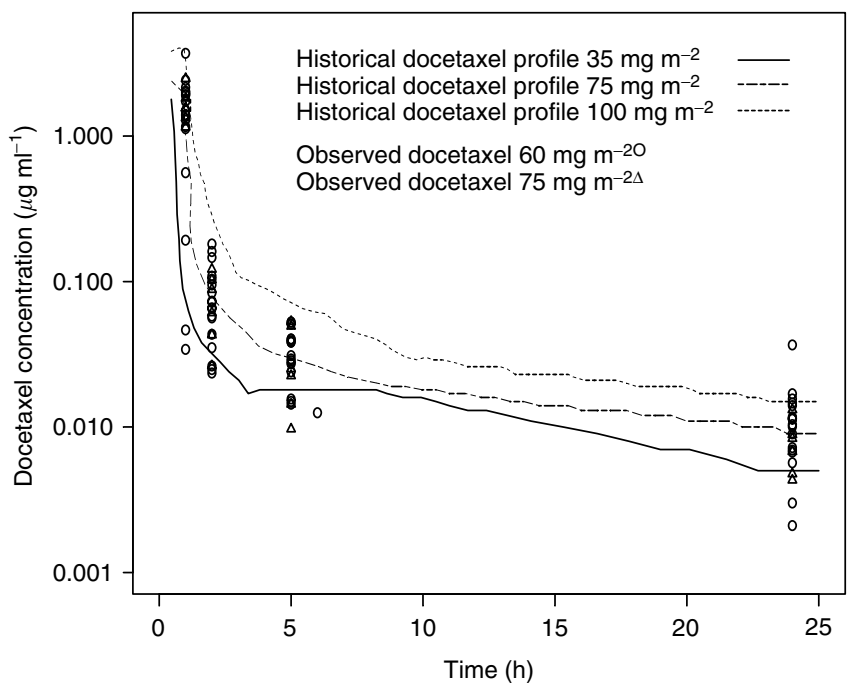

Figure 2 Observed and historical docetaxel concentration time profiles. Graph showing concentration time profiles of docetaxel for patients in this study (at 60 and $75 \mathrm{mg} \mathrm{m}^{-2}$ ) compared to historical controls (at 35, 75 and $\left.100 \mathrm{mg} \mathrm{m}^{-2}\right)$.

\section{Response}

There were no confirmed complete or partial responses. A total of seven patients had a best response of stable disease (SD) lasting $\geqslant 18$ weeks (six HRPC and one renal cell cancer), including one patient with HRPC demonstrating SD for $\geqslant 24$ weeks. Of the patients with HRPC, one demonstrated a confirmed $>50 \%$ decrease in the serum level of prostatic-specific antigen (PSA).

\section{DISCUSSION}

Antimitotic agents targeting tubulin, including the vinca alkaloids and taxanes, are arguably the most successful anticancer drugs developed to date. These findings have fuelled the development of novel antimitotics to improve drug disposition, decrease toxicity or improve efficacy. Recent drug discovery strategies have focused on the development of targeted agents that block the function of key enzymes involved in mitosis, such as the aurora kinases, pololike kinase-1 (PLK-1) and the kinesins CENP-E and KSP (Blagden and de Bono, 2005; Jackson et al, 2007). These agents have shown promise in preclinical studies, and early clinical trial data indicate that they are well tolerated at biologically active doses, with neutropaenia being dose-limiting and showing little evidence of neurotoxicity. This improved toxicity profile may be advantageous; however, concerns remain about the basis for selective cytotoxicity with these agents. Moreover, owing to the neutropaenia associated with these drugs, combining these agents with established cytotoxics at recommended doses may be difficult.

In this phase I dose escalation study, ispinesib was combined with docetaxel. The drugs were administered consecutively on day 1 of a 21-day schedule and 24 patients were treated. No evidence of a drug-drug PK interaction was observed. The MTD for this study was defined as $10 \mathrm{mg} \mathrm{m}^{-2}$ of ispinesib and $60 \mathrm{mg} \mathrm{m}^{-2}$ of docetaxel. The tolerability profile was predictable, acceptable and manageable, with neutropaenia and leukopaenia occurring at a similar frequency to that seen with single agent docetaxel (Taxotere ${ }^{\circledR}$, 2005). There was also sparing of the other haematopoietic lineages, which was also evident in phase I single agent studies of ispinesib (Chu et al, 2003, 2004; Burris et al, 2004). Peripheral neurotoxicity was generally mild and rarely seen, with grade 2 neuropathy observed in two patients receiving this regimen, supporting evidence that this novel targeted antimitotic is not by itself neurotoxic. Nonetheless, the cumulative overall administered dose of docetaxel in this study was low and may also partly explain the low rate of significant neurotoxicity.

The toxicity profile observed in this study was similar to that observed in preliminary reports of other phase I studies combining ispinesib with cytotoxic agents (Jones et al, 2006; Rodon et al, 2006). Rodon et al (2006) reported a DLT of grade 4 neutropaenia when ispinesib and capecitabine were administered on day 1 and days 1 -14, respectively, of a 21-day schedule. However, Jones et al (2006) reported a DLT of grade 4 neutropaenia when ispinesib was combined with carboplatin on a day 1 every 21-day schedule.

The best objective tumour response observed was disease stabilisation lasting $\geqslant 18$ weeks in seven patients - six with HRPC and one with renal cell cancer. However, in this study, just one patient with HRPC demonstrated a confirmed $\geqslant 50 \%$ decline in PSA (Bubley et al, 1999). This low PSA 50\% decline rate in advanced HRPC patients may be attributed to the suboptimal dose of docetaxel administered, but it appears to suggest that KSP blockade does not increase the antitumour activity at the dose levels and schedule evaluated in this study.

Second generation KSP inhibitors are now in the clinic (Holen et al, 2006; Stein et al, 2006). SB-743921 is five-fold more potent than ispinesib against the ATPase activity of KSP and demonstrates cytotoxic activity at $<2 \mathrm{~nm}$ in a range of tumour cell lines (Jackson et al, 2006). It has been tested in 44 solid cancer patients in a phase I study as a $1 \mathrm{~h}$ infusion administered every 21 days (Holen et al, 2006). The MTD has been defined as $4 \mathrm{mg} \mathrm{m}^{-2}$. MK-0731 has demonstrated an IC $_{50}$ of $2.2 \mathrm{~nm}$ in several tumour cell lines and has been administered as a $24 \mathrm{~h}$ infusion every 21 days in eight patients so far (Stein et al, 2006). The MTD was exceeded at $48 \mathrm{mg} \mathrm{m}^{-2}$ and the recommended phase II dose is being explored. The preliminary reports of these two agents have shown a similar toxicity profile to ispinesib with DLTs of prolonged neutropaenia (Holen et al, 2006; Stein et al, 2006). The non-haematological toxicity profile of MK-0731 was similar to that of ispinesib with respect to gastrointestinal and constitutional toxicities; however, in contrast to our study and those of single agent ispinesib, mucositis, nail changes and phlebitis were reported (Stein et al, 2006). In addition, transaminitis, hyperbilirubinaemia and hypophosphataemia were reported with SB-743921 (Holen et al, 2006).

In conclusion, this study demonstrated that docetaxel can be safely administered with a KSP inhibitor but that non-cumulative neutropaenia limits the dosing of both these agents. Careful consideration needs to be given now to optimise the evaluation of the mitotic kinesin inhibitors through rational drug combinations that can lead to selective tumour cytotoxicity.

\section{REFERENCES}

Baker SD, Zhao M, Lee CKK, Verweij J, Zabelina Y, Brahmer JR, Wolff AC, Sparreboom A, Carducci MA (2003) Comparative Pharmacokinetics of weekly and every three weeks docetaxel. Clin Cancer Res 10: $1976-1983$

Blagden S, de Bono J (2005) Drugging cell cycle kinases in cancer therapy. Curr Drug Targets 6: $325-335$

Blangy A, Lane HA, d'Herin P, Harper M, Kress M, Nigg EA (1995) Phosphorylation by $\mathrm{p} 34 \mathrm{cdc} 2$ regulates spindle association of human Eg5, a kinesin-related motor essential for bipolar spindle formation in vivo. Cell 83: $1159-1169$

Bubley GJ, Carducci M, Dahut W, Dawson N, Daliani D, Eisenberger M, Figg WD, Freidlin B, Halabi S, Hudes G, Hussain M, Kaplan R, Myers C, 
Oh W, Petrylak DP, Reed E, Roth B, Sartor O, Scher H, Simons J, Sinibaldi V, Small EJ, Smith MR, Trump DL, Vollmer R, Wilding G (1999) Eligibility and response guidelines for phase II clinical trials in androgen-independent prostate cancer: recommendations from the Prostate-Specific Antigen Working Group. J Clin Oncol 17: 3461-3467

Burris HA, Lorusso P, Jones S, Guthrie TM, Orr JB, Williams DD, Hodge JP, Bush M, Sabry J (2004) Phase I trial of novel kinesin spindle protein (KSP) inhibitor SB-715992 IV days 1, 815 q 28 days. Proc Am Soc Clin Oncol 22: 14S

Chan S, Friedrichs K, Noel D, Pintér T, Van Belle S, Vorobiof D, Duarte R, Gil MG, Bodrogi I, Murray E, Yelle L, von Minckwitz G, Korec S, Simmonds P, Buzz Fi, González-Mancha R, Richardson G, Walpole E, Ronzoni M, Murawsky M, Alakl M, Riva A, Crown J (1999) Prospective randomized trial of docetaxel versus doxorubicin in patients with metastatic breast cancer. J Clin Oncol 17: $2341-2354$

Chu Q, Holen KD, Rowinsky EK, Wilding G, Volkman JL, Orr JB, Williams DD, Hodge JP, Sabry J (2004) A Phase I trial of novel kinesin spindle protein (KSP) inhibitor SB-715992 IV q 21 days. Proc Amer Soc Clin Oncol 22: 2078

Chu QS, Holen KD, Rowinsky EK, Alberti DB, Monroe P, Volkman JL, Hodge JP, Sabry J, Ho PTC, Wilding G (2003) A phase I study to determine the safety and pharmacokinetics of IV administered SB715992 , a novel kinesin spindle protein (KSP) inhibitor in patients with solid tumors. Proc Am Soc Clin Oncol 22: 525

Cochran JC, Gatial III JE, Kapoor TM, Gilbert SP (2005) Monastrol inhibition of the mitotic kinesin Eg5. J Biol Chem 280: 12658-12667

Drinka PJ, Langer E (1989) The Cockroft - Gault formula. J Am Geriatr Soc 37: 820

Eisenhauer EA, Vermorken JB (1998) The taxoids: comparative clinical pharmacology and therapeutic potential. Drugs 55: 5-30

Fossella F, Pereira JR, von Pawel J, Pluzanska A, Gorbounova V, Kaukel E, Mattson KV, Ramlau R, Szczesna A, Fidias P, Millward M, Belani CP (2003) Randomized, multinational, phase III study of docetaxel plus platinum combinations versus vinorelbine plus cisplatin for advanced non-small-cell lung cancer: the TAX 326 Study Group. J Clin Oncol 21: 3016-3024

Fossella FV, DeVore R, Kerr RN, Crawford J, Natale RR, Dunphy F, Kalman L, Miller V, Lee JS, Moore M, Gandara D, Karp D, Vokes E, Kris M, Kim Y, Gamza F, Hammershaimb L (2000) Randomized phase III trial of docetaxel versus vinorelbine or ifosfamide in patients with advanced non-small-cell lung cancer previously treated with platinum-containing chemotherapy regimens. J Clin Oncol 18: 2354-2362

Hegde PS, Cogswell J, Carrick K, Jackson J, Wood KW, Eng WK, Brawner M, Huang PS, Bergsma D (2003) Differential gene expression analysis of kinesin spindle protein in human solid tumors. Proc Am Soc Clin Oncol 22: 535

Holen KD, Belani CP, Wilding G, Ramalingam S, Heideman JL, Ramanathan RK, Bowen CJ, Williams DD, Hodge JP, Dar MM (2006) Phase I study to determine tolerability and pharmacokinetics (PK) of SB743921, a novel kinesin spindle protein (KSP) inhibitor. Proc Am Soc Clin Oncol 24: 2000

Jackson JR, Gilmartin A, Dhanak D, Gilmartin A, Dhanak D, Knight S, Parrish C, Luo L, Sutton D, Caulder E, Diamond M, Giardiniere M, Zhang SY, Huang P, Bergnes G, McDonald A, Lee Y, Sakowicz R, Wood KW (2006) A second generation KSP inhibitor, SB-743921, is a highly potent and active therapeutic in preclinical models of cancer. Proc Am Assoc Cancer Res 2006: B11

Jackson JR, Patrick DR, Dar MM, Huang PS (2007) Targeted anti-mitotic therapies: can we improve on tubulin agents? Nat Rev Canc 7: 107-117
Johnson RK, McCabe FL, Cauder E, Inlow-Porter L, Whitacre M, Winkler JD, Bergnes G, Feng B, Morgans D, Wood KW, Jackson JR (2002) SB-715992, a potent and selective inhibitor of KSP mitotic kinesin, demonstrates broad-spectrum activity in advanced murine tumors and human tumor xenografts. Proc Am Assoc Cancer Res 43: 269

Jones SF, Plummer ER, Burris HA, Razak AR, Meluch AA, Bowen CJ, Williams DH, Hodge JP, Dar MM, Calvert AH (2006) Phase I study of ispinesib in combination with carboplatin in patients with advanced solid tumors. Proc Am Soc Clin Oncol 24: 2027; 18 S

Mayer TU, Kapoor TM, Haggarty SJ, King RW, Schreiber SL, Mitchison T (1999) Small molecule inhibitor of mitotic spindle bipolarity identified in a phenotype-based screen. Science 286: $971-974$

Miller K, Ng C, Ang P, Brufsky AM, Lee SC, Dees EC, Piccart M, Verrill M, Wardley A, Loftiss J, Bal J, Yeoh S, Hodge J, Williams D, Dar M, Ho PTC (2005) Phase II, Open Label Study of Ispinesib in Patients with Locally Advanced or Metastatic Breast Cancer. San Antonio Breast Cancer Symposium 2005: 1089

Nabholtz J-M, Senn HJ, Bezwoda WR, Melnychuk D, Deschênes L, Douma J, Vandenberg TA, Rapoport B, Rosso R, Trillet-Lenoir V, Drbal J, Molino A, Nortier JWR, Richel DJ, Nagykalnai T, Siedlecki P, Wilking N, Genot JY, Hupperets PSGJ, Pannuti F, Skarlos D, Tomiak EM, Murawsky A, Alakl M, Riva A, Aapro M (1999) Prospective randomized trial of docetaxel versus mitomycin plus vinblastine in patients with metastatic breast cancer progressing despite previous anthracyclinecontaining chemotherapy. J Clin Oncol 17: 1413-1424

Rodon J, Till E, Patnaik A, Takimoto C, Beeram M, Williams D, Bowen C, Hodge J, Dar M, Tolcher A (2006) Phase I study of ispinesib (SB-715992), a kinesin spindle protein inhibitor, in combination with capecitabine in patients with advanced solid tumors. Eur J Canc Suppl 4: 193

Sakowicz R, Finer JT, Beraud C, Crompton A, Lewis E, Fritsch A, Lee Y, Mak J, Moody R, Turincio R, Chabala JC, Gonzales P, Roth S, Weitman S, Wood KW (2004) Antitumor activity of a kinesin inhibitor. Cancer Res 64: $3276-3280$

Shahin M, Braly P, Rose P, Malpass T, Bailey H, Alvarez RD, Hodge J, Bowen C, Buller R (2007) A phase II, open-label study of ispinesib (SB715992 ) in patients with platinum/taxane refractory or resistant relapsed ovarian cancer. Proc Am Soc Clin Oncol 21: 5562

Shepherd FA, Dancey J, Ramlau R, Mattson K, Gralla R, O’Rourke M, Levitan N, Gressot L, Vincent M, Burkes R, Coughlin S, Kim Y, Berille J (2000) Prospective randomized trial of docetaxel versus best supportive care in patients with non-small-cell lung cancer previously treated with platinum-based chemotherapy. J Clin Oncol 18: $2095-2103$

Stein MN, Rubin EH, Scott PD, Fernandez R, Agrawal NG, Hsu K, Walker A, Holen K, Wilding G (2006) Phase I clinical and pharmacokinetic (PK) trial of the kinesin spindle protein (KSP) inhibitor MK-0731 in cancer patients. Proc Am Soc Clin Oncol 24: 2001

Tannock IF, de Wit R, Berry WR, Horti J, Pluzanska A, Chi KN, Oudard S, Théodore C, James ND, Turesson I, Rosenthal MA, Eisenberger MA (2004) Docetaxel plus prednisone or mitoxantrone plus prednisone for advanced prostate cancer. $N$ Engl J Med 351: $1502-1512$

Taxotere $^{\mathbb{R}}$ Prescribing Information (2005). Bridgewater, NJ: Aventis Pharmaceuticals Inc.

Therasse P, Arbuck SG, Eisenhauer EA, Wanders J, Kaplan RS, Rubinstein L, Verweij J, van Glabbeke M, van Oosterom AT, Christian MC, Gwyther SG (2000) New guidelines to evaluate the response to treatment in solid tumors. J Natl Cancer Inst 92: 205-216

Wood KW, Cornwell WD, Jackson JR (2001) Past and future of the mitotic spindle as an oncology target. Curr Opin Pharmacol 1: 370-377 